University of Tennessee Law

Legal Scholarship Repository: A Service of the Joel A. Katz Library

UTK Law Faculty Publications

Winter 2018

Congressional Control of Presidential Pardons

Glenn Harlan Reynolds

Follow this and additional works at: https://ir.law.utk.edu/utklaw_facpubs

Part of the Law Commons 


\title{
CONGRESSIONAL CONTROL OF PRESIDENTIAL PARDONS
}

\author{
Glenn Harlan Reynolds*
}

\begin{abstract}
INTRODUCTION
The reach of the presidential pardon power has been much in the news of late (for a variety of reasons). ${ }^{1}$ It is well established that the pardon power is plenary ${ }^{2}$ that it can be exercised in advance of formal criminal charges being filed $;^{3}$ and that it does not extend to state crimes $;^{4}$ but there remain many unsettled (and unsettling) questions. Can a president pardon himself? ${ }^{5}$ Can a pardon, though perfectly lawful in itself, constitute obstruction of justice? Can a president use a pardon, issued in advance of criminal activity, to insulate an actor from criminal liability before the criminal act is even complete? These are interesting questions, but I intend to address a related, but broader, question: To what extent may Congress, via legislation, regulate the president's pardon power? Though it is well established that the power is plenary, does that insulate the pardon power from any Congressional regulation or oversight at all? And if the answer to this question is "no" (and it likely is), then what sort of Congressional regulations and oversight are permissible? I will address these issues in this short Essay and offer some suggestions for how Congress might lawfully regulate, or at least regularize, the pardon power.
\end{abstract}

\footnotetext{
* Beauchamp Brogan Distinguished Professor of Law, University of Tennessee. J.D. Yale Law School; B.A. University of Tennessee.

${ }^{1}$ See, e.g., Jonathan Turley, Does Trump Have Total Power to Pardon? He Just Might, HiLL (July 24, 2017), http://thehill.com/blogs/pundits-blog/the-administration/343408-opiniondoes-trump-have-complete-power-to-pardon-he.

${ }^{2}$ Ex parte Garland, 71 U.S. 333 (1866) (discussing the extensive, plenary nature of the presidential pardon power). See generally Presidential Pardon Power: Hearing Before the Subcomm. on the Constitution of the H. Comm. on the Judiciary, 107 Cong. (2001) (discussing scope and nature of the presidential pardon power); JEFFREy CROUCH, THE PRESIDENTIAL PARDON POWER 9-27 (2009) (discussing extent of the presidential pardon power).

${ }^{3}$ Ex parte Garland, 71 U.S. at 380 ("[The presidential pardon power] extends to every offence known to the law, and may be exercised at any time after its commission, either before legal proceedings are taken, or during their pendency, or after conviction and judgment.").

${ }^{4}$ See, e.g., Frequently Asked Questions Concerning Executive Clemency, U.S. DEP'T JuST. (Oct. 30, 2017), https://www.justice.gov/pardon/frequently-asked-questions-concerningexecutive-clemency.

5 See generally, e.g., Andrew Rudalevige, Here's What You Need to Know About the Presidential Power to Pardon, WASH. POST (July 24, 2017), https://www.washingtonpost.com/news/monkey-cage/wp/2017/07/24/heres-what-you-needto-know-about-the-presidential-power-to-pardon/?utm_term=.0bd65edf1a2f; Turley, supra note 1 .
} 


\section{CONGRESSIONAL POWER TO Regulate}

It is straightforward that Congress has at least some ability to regulate the pardon power. For instance, the pardon power clause itself has a built-in exception: "[The president] shall have Power to grant Reprieves and Pardons for Offences against the United States, except in Cases of Impeachment." Additionally, the Supreme Court has recognized Congress's general "investigative power" derived from its legislative powers. ${ }^{7}$ Arguably bolstering these Congressional powers to place at least some limitations on the presidential pardon power is Article 1, section 8, clause 18 of the Constitution, which provides,

The Congress shall have Power To ... make all Laws which shall be necessary and proper for carrying into Execution the foregoing Powers, and all other Powers vested by this Constitution in the Government of the United States, or in any

Department or Officer thereof. ${ }^{8}$

The most common discussion of the "necessary and proper" clause has to do with Congress's use of this power to extend, or build upon, other enumerated powers, as in the famous landmark case of McCulloch v. Maryland..$^{9}$ But the clause expressly applies to "all other Powers vested by this Constitution in the Government of the United States, or in any Department or Officer thereof."

This sweeping language seems rather plainly to encompass any power vested anywhere by the Constitution. Since the president's power to issue pardons is itself a power vested by the Constitution in an "Officer"- the president-it would be difficult to argue that the pardon power does not fall at least partially within the necessary and proper clause's sweep. That being the case, if Congress has the power to make all laws necessary and proper for carrying into

${ }^{6}$ U.S. CONST. art. II, $\S 2$, cl. 1 (emphasis added). One scholar discussed this exception as follows:

The one time when Congress may have an absolute right to obtain testimony and documents related to presidential pardons is in the context of an impeachment investigation. Once the impeachment process has begun, Congress has plenary authority to obtain whatever information it needs to complete its investigation, and it therefore seems to be generally recognized that executive privilege will not shield even the President from producing documents relating to an impeachment inquiry. This should apply in the context of a pardon inquiry that is a legitimate part of an impeachment investigation and permit Congress to obtain documents and testimony relating to presidential pardons.

Todd David Peterson, Congressional Power over Pardon \& Amnesty: Legislative Authority in the Shadow of Presidential Prerogative, 38 WAKE FOREST L. REV. 1225, 1268 (2003) (footnotes omitted).

7 See Watkins v. United States, 354 U.S. 178, 187 ("The power of the Congress to conduct investigations is inherent in the legislative process. That power is broad. It encompasses inquiries concerning the administration of existing laws as well as proposed or possibly needed statutes. It includes surveys of defects in our social, economic or political system for the purpose of enabling the Congress to remedy them. It comprehends probes into departments of the Federal Government to expose corruption, inefficiency or waste. . . . [However n]o inquiry is an end in itself; it must be related to, and in furtherance of, a legitimate task of the Congress."). See generally Peterson, supra note 6, at 1262-68 (2003) (discussing the scope of Congress's investigative power in the context of pardons).

${ }^{8}$ U.S.CONST. art. I, $\$ 8$, cl. 18 (emphasis added).

917 U.S. $316(1819)$. 
execution the president's pardon power (by, for instance, creating the Justice Department and a Pardon Attorney Office therein), then Congress should have the power to make all laws necessary and proper for limiting the ability of those offices and officers to abuse their congressionally-created powers. Congress could argue that, even if it has no authority to limit the president himself from physically signing a pardon, Congress might be able to limit other Officers (e.g., the Pardon Attorney) and, even more generally, the entire executive apparatus supporting the president's pardon power authority (i.e., the Justice Department). ${ }^{10}$ Any contrary reading would do violence to the clause, and would likely produce substantial collateral damage with regard to other exercises of congressional power under this provision.

\section{What Kind OF REgUlation Is PeRMitTEd?}

If Congress has the power to make all laws necessary and proper for carrying into execution the president's pardon power, what sort of laws could Congress enact that might limit, or at least impose certain informational requirements on, the exercise of the pardon power? Congress may have the power to legislate here, but in doing so it is nonetheless limited by the nature of the pardon power: It is a plenary power, exercisable at the sole discretion of the president. The history of the pardon provision makes clear that the Framers considered and rejected proposals to subject its exercise to direct control by Congress, such as by requiring legislative approval. ${ }^{11}$ So any legislation that would have the effect of tying the president's hands, or allowing Congress to interfere with the president's power to grant pardons-for example, by limiting the president's discretion in terms of choosing the circumstances, beneficiaries, scope, or conditions of pardons - would excessively (and therefore unconstitutionally)

${ }^{10}$ See Peterson, supra note 6, at 1255 ("[T] Attorney Reform and Integrity Act, S. 2042, 106th Cong. (2000), H.R. 3626, 106th Cong. (2000)] ought to be within the legislative power of Congress. Although . . . Congress could not deprive the President of the pen and paper with which to sign a pardon - there is no constitutional requirement that Congress appropriate funds for an executive branch department to provide the President with advice on pardon matters.").

11 This debate is discussed in THE FEDERALIST No. 74 (Alexander Hamilton):

The expediency of vesting the power of pardoning in the President has, if I mistake not, been only contested in relation to the crime of treason. This, it has been urged, ought to have depended upon the assent of one, or both, of the branches of the legislative body. I shall not deny that there are strong reasons to be assigned for requiring in this particular the concurrence of that body, or of a part of it. As treason is a crime levelled at the immediate being of the society, when the laws have once ascertained the guilt of the offender, there seems a fitness in referring the expediency of an act of mercy towards him to the judgment of the legislature. And this ought the rather to be the case, as the supposition of the connivance of the Chief Magistrate ought not to be entirely excluded. But there are also strong objections to such a plan.

The Federalist Papers: Federalist No. 74, CONGRESs.gov: Resources, https://www.congress.gov/resources/display/content/The+Federalist+Papers\#TheFederalistP apers-74 (last visited Dec. 18, 2017). See generally CROUCH, supra note 2, at 16-17 (describing Framers' debates). 
interfere with the president's exercise of that broad plenary power. ${ }^{12}$

What does that leave then? Quite a lot, actually. Although Congress cannot tie the president's hands, it seems likely that it could take substantial steps to ensure that, under certain circumstances, those hands perform their actions in the open - and if not open to the entire public, then at least behind closed doors to Congress. Rules providing for such transparency would very likely withstand constitutional scrutiny given that a pardon is, by its nature, a public act. What sort of rules might those be? Rules intended to ensure notice, understanding, and accountability to Congress and/or the public, such as requirements for:

1. Archiving. An archiving requirement would ensure that presidential pardons are recorded and preserved by the National Archives and Records Administration. For instance, Congress might require that, within 72 hours of executing a pardon, a copy be deposited with the Archivist of the United States, and be made publicly available via the National Archives. Congress could condition funding for certain executive branch offices on the administration's compliance. ${ }^{13}$ (Congress might even provide - though this is much more of a stretchthat pardons issued without such notice might be ineffective, or reversible by the next president).

2. Explanation. Congress might further require that pardons be accompanied by a short and clear explanation of the reason for the pardon. Requiring such a statement would not limit what the president does, but rather would require that he or she account to the public (or at least to Congress) for an action that, after all, is by its very nature (and by design) a departure from the ordinary administration of justice. Where the pardon is for a crime against individual victims (as opposed to offenses against public institutions), Congress might require that a copy of this explanation be delivered directly to those victims.

3. Accounting. The Archivist might maintain an index of pardons by crimes and circumstances, so that each new pardon might easily be compared to prior pardons and their treatment of similar crimes and circumstances in the past. Over time, this would make it easier to determine when a particular use of the pardon power is unusual or inconsistent.

None of these rules (or, in the same vein, other types of informational requirements that Congress might devise) would directly limit the ability of presidents to pardon individuals or groups. Such rules would, however, provide a substantial degree of additional scrutiny and accountability. The archiving requirement in particular would prevent unscrupulous presidents from issuing pardons in advance of illegal acts - whether such a president would be pardoning himself, his family, or others - and withholding those pardons from public scrutiny (perhaps by keeping them in the family safe or in a desk drawer) until they are ultimately needed..$^{14}$

${ }^{12}$ See United States v. Klein, 80 U.S. 128 (1871) (establishing that Congress cannot undo pardons or legislatively circumscribe their objects).

13 See supra note 10.

${ }^{14}$ There is dicta in Ex parte Garland and Ex parte Grossman to the effect that pardons cannot be issued in advance of a crime, but such statements are, at present, only dicta. Ex parte 
Informational requirements would constrain a number of such abuses, ranging from a president secretly issuing himself or herself a blanket pardon at the end (or beginning!) of a term of office, to a president's use of advance secret pardons as a form of "carte blanche," get-out-of-jail-free card allowing favored retainers to violate the law at the president's direction without fear of subsequent prosecution or consequence (even by a successor administration). A president could still issue such nefarious pardons, but they would no longer be secret-which, in terms of public and political backlash, would substantially limit their (nefarious) utility. The relevant retainers might be less convinced that such pardons would be honored, and more concerned about extralegal political consequences, since such pardons would be strong evidence of skullduggery even if they prevented prosecution. ${ }^{15}$

Indeed, all regulations of this kind would serve to limit the president's plenary power to pardon anyone he or she desires only indirectly, via political pressure. Such indirect regulation is not unknown, of course, in other contexts: Many statutes involving international trade, human rights, etc. grant discretion to the president but require him to first make findings or declarations that may prove politically embarrassing if insufficiently founded. Likewise, administrative law, which deals with actions by executive branch offices, makes use of procedural requirements and information accessibility as a form of political constraint to bound agency discretion.

Congress's power to act in this fashion is hard to dispute. As Chief Justice Marshall wrote in discussing the necessary and proper power in McCulloch:

Let the end be legitimate, let it be within the scope of the constitution, and all means which are appropriate, which are plainly adapted to that end, which are not prohibited, but consist with the letter and spirit of the constitution, are constitutional.

$\cdots$

... [W] here the law is not prohibited, and is really calculated to effect any of the objects intrusted to the government, to undertake here to inquire into the degree of its necessity, would be to pass the line which circumscribes the judicial department, and to tread on legislative ground. This court disclaims all preten-

Grossman, 267 U.S. 87, 121 (1925) ("[A] pardon can only be granted for a [criminal] contempt fully completed.”); Ex parte Garland, 71 U.S. 333, 380 (1866) (stating a pardon may be issued at any time after the commission of a criminal offense). Even if a pardon issued in advance of a crime were retroactively invalidated by the Court, the recipient of that pardon might be able to, in effect, re-validate it via a defense of entrapment, arguing that he committed a crime only because the nation's chief law enforcement official, the President, promised that it would not be prosecutable.

${ }^{15}$ See Peterson, supra note 6, at 1235-36 ("This issue was, of course, most famously raised by President Ford's pardon of Richard Nixon. Although President Ford cataloged a long list of reasons why the pardon was in the public interest, public suspicion persisted that President Ford had granted the pardon as a quid pro quo for President Nixon's agreement to resign or for other political reasons. In order to quell suspicions about the pardon, President Ford took the unprecedented step of appearing personally before a congressional committee to answer written and oral questions about the Nixon pardon." (footnotes omitted)). 
sions to such a power. ${ }^{16}$

By legislating to regularize and open up the exercise of the pardon power to at least some minimum level of public scrutiny, Congress would not be directly interfering with the president's prerogative, and it strikes me as unlikely that federal courts would find otherwise.

\section{BENEFITS}

Regularized procedure and informational requirements imposed on the presidential pardon power would deliver transparency and accountability to a process that has been, up to now, significantly lacking in both. Recent events seem to suggest that the threat of surreptitious presidential pardons has the potential to get worse, if not in the current administration then in future ones. By raising at least the prospect that pardon-related skullduggery might be detected, subjected to public and political scrutiny, and perhaps - in extreme casesoverturned as an unlawful abuse of power (or at least rendered politically explosive), it would make that sort of behavior less expedient and therefore less likely to occur in the first place. And, of course, it would help to establish clearer norms regarding which uses of the pardon power are acceptable, and which constitute an abuse of the president's discretion, however vast that discretion may be.

\section{CONCLUSION}

To date, the pardon power has been the source of relatively little constitutional friction between Congress and the president. Though there have been a few cases in which pardons were granted under circumstances that could fairly be described as "shady," 17 those cases involved questions of ordinary misbehavior at most, rather than the sort of thing that might produce a more serious political and/or constitutional crisis. In this, we have been lucky (so far).

Luck, however, does not last forever. If it is possible to imagine that a president might establish a corps of underlings privileged by advance pardons to violate the criminal law in service of his or her political goals (and such a thing is not all that difficult to imagine), then it is possible that such a thing might happen. Likewise, the prospect of a president pardoning himself (or herself) for illegal conduct is hardly beyond imagination. (And, even if the ability to selfpardon is, as some might argue, an essential weapon in a president's arsenal of self-protection and immunity, it would be best for the public that such a pardon be granted transparently.)

What is more, all that is needed to put this remedy in place is the passage of legislation that is likely to be, at least as a matter of politics, noncontrover-

${ }^{16}$ McCulloch v. Maryland, 17 U.S. 316, 421, 423 (1819).

17 See, e.g., Crouch, supra note 2, at 2 (describing pardons by George H.W. Bush of Caspar Weinberger and other figures in the Iran-Contra scandal; pardons by William J. Clinton of financier and contributor Marc Rich; and commutation by George W. Bush of aide Lewis "Scooter" Libby). 
sial. Such legislation would not tie a president's hands, and it would certainly help establish clearer norms against which future presidential behavior may be measured. In the present age, such norms would be most welcome. To the extent that presidential discretion to award pardons is (or becomes) a question of presidential abuse of power, I hope that this paper has demonstrated that there is a solution: in the form of legislation that Congress likely has the power to enact. We should fervently wish that all of our current political problems might be so easily solved. 